\title{
Comorbidity of Stuttering and Disordered Phonology in Young Children
}

\author{
Lesley Wolk, Ph.D (Syracuse University) \\ Edward G. Conture, Ph.D (University of Iowa) \\ Mary Louise Edwards, Ph.D (Stanford University) \\ Department of Communication Sciences and Disorders \\ Syracuse University \\ Syracuse, New York, USA
}

\begin{abstract}
Young stutterers frequently exhibit concomitant speech and/or language disorders. The co-occurrence of these disorders is, however. not yet well understood. The purpose of this paper is to introduce the notion of "comorbidity" as it relates to the field of speech-language pathology: specifically, to discuss comorbidity (coexistence) of stuttering and disordered phonology in young child ren. Literature on concomitant speech and language disorders in young stutterers is reviewed, with special reference to the prevalence of articulatory/phonological disorders in young stutterers. Future research on the coexistence of two speech and language disorders is encouraged, as well as the consideration of diagnostic treatment and prognostic implications for children who exhibit both stuttering and disordered phonology as opposed to child ren who exhibit each disorder in isolation.
\end{abstract}

\section{OPSOMMING}

Jong hakkelaars vertoon dikwels samegaande spraak-en/oftaalafulykings. Die gelyktydige voorkoms van hierdie afwykings word tans egter nie ten volle begrup nic. Die doel van hierdie artikel is om die begrip van "ko-morbiditeit" bekend te stel sons wat dit tocgepas word op die vakgebied van spraakheelkunde en ook spesifick om die gelyktydige voorkoms van hakkel en fonologiese afwykings in jong kinders te bespreek. 'n Literatuuroorsig van die gelyktydige voorkoms van spraak-en taala fulgkings in jong hakkelaars word verskaf, met spesiale verwysing na dic voorkoms van a rtikulasie/fonologiese afu, taala fuykings word aangemoedig. Die oorweging van diagnostiese, behandelings en prognostiese implikasies vir kinders wat beide hakkel en afuykende fonologiese ontuikkeling vertoon, in teenstelling met kinders wat elke afwyking afsonderlik vertoon, word a angebied.

Comorbidity refers to "... any distinct additional clinical entity that has existed or that may occur during the clinical course of a patient who has the index disease under study" (Feinstein, 1970, p. 456). Comorbidity has been discussed in some detail in the medical literature, particularly in relation to psychiatric disorders (Boyd, Burke, Gruenberg, Holzer, Kae, George, Karno, Stoltzman, McEvoy \&:Nestadt, 1984; Feinstein, 1970). Yet it has received little attention in the field of speechlanguage pathology. Although children with more than one speech disorder (e.g., stuttering and disordered phonology) are encountered frequently in clinical practice, there has been a paucity of research dedicated to understanding the coexistence and inter-relationships between two speech disorders. Indeed, Stuttering (S) and Disordered Phonology (DP) have traditionally been investigated and treated as two distinct disorders. Little attempt has been made to merge the two disorders in terms of the following: (1) investigation of their cooccurrence in some children; (2) therapy regimens when both disorders are exhibited in the same child; and (3) conceptual explanations for their co-existence, and in some cases, persistence

The general purpose of this paper is to introduce the notion of "comorbidity" as it relates to the field of speech-language pathology. The more specific aim is to discuss the comorbidity (co-existence) of stuttering and disordered phonology exhibited in young children. Literature on concomitant speech and language disorders in young stutterers is reviewed, with special reference to the prevalence of articulatory/phonological disorders in young stutterers.

Understanding the coexistence of two speech disorders in particular, Stuttering (S) and Disordered Phonology (DP), has clinical implications, for example, differential diagnosis, such as the possibility of behavioral subgroups of young stutterers. Further, diagnostic treatment an'd prognostic features may be different for children who exhibit the co-occurrence of two speech disorders as opposed to each disorder in isolation. Feinstein (1970, p. 456) states: "With comorbidity omitted from consideration, two clinicians arguing about the merits of a mode of treatment for a particular disease may fail to recognize that their contradictory results arise not from the actions of treatment, but from the different associated diseases in the patients subjected to treatment."

Regarding the co-occurrence of stuttering and disordered phonology in young children, several studies have investigated the prevalence of their coexistence (e.g., Blood \& Seider, 1981; Daly, 1981). These studies are presented and discussed in detail below. In general, findings from previous studies have shown that $30-40 \%$ of young stutterers also exhibit articulation/phonological concerns (see Table 1 below). However, only a few studies have attempted to explore the nature of this co-occurrence in more depth (e.g., St. Louis \& 
Hinzman, 1988; Louko, Conture \& Edwards, 1990). Thus, little objective information is available regarding the nature and relation of these two disorders in young children. Because it appears that approximately one third of children who stutter at one time or another exhibit articulation difficulties (e.g., Cantwell \& Baker, 1985), it would seem important to increase our understanding of the nature and relation between stuttering and articulatory/phonological disorders in young children.
To further highlight the existence and clinical importance of the co-occurrence of these two disorders, it is noted that clinicians frequently report that young children who are being treated for articulation difficulties may subsequently begin to stutter. Comas (1974, cited in Bloodstein, 1987, p. 221) reported that out of 1,050 cases of young children, in some, stuttering was observed to appear while they were being treated for articulation difficulties. In addition, with reference to child-

\section{Table 1: Published Studies on the Co-occurrence of Stuttering and Articulation/Phonological Difficulties in Young} Children

\begin{tabular}{|c|c|c|c|c|c|c|c|}
\hline Author & Date & Stut. & Nonstut. & $\begin{array}{l}\text { Source of } \\
\text { Information }\end{array}$ & $\begin{array}{c}\% \\
\text { Stut. } \\
\text { with } \\
\text { Artic. } \\
\text { Diff. }\end{array}$ & $\begin{array}{c}\% \\
\text { Nonstut. } \\
\text { with } \\
\text { Artic. } \\
\text { Diff. }\end{array}$ & $\begin{array}{l}\text { Summary } \\
\text { of } \\
\text { Findings }\end{array}$ \\
\hline 1. McDowell & $(1928)$ & 33 & 33 & $\begin{array}{l}\text { Speech Exam. } \\
\text { (Articulation } \\
\text { Test) }\end{array}$ & $19 \%$ & $16 \%$ & $\begin{array}{l}\text { articulation difficul- } \\
\text { ties with significant } \\
\text { difference between } \\
\text { groups }\end{array}$ \\
\hline 2. Schindler & $(1955)$ & 126 & 252 & Speech Exam. & $49 \%$ & $15 \%$ & $\begin{array}{l}\text { "other speech } \\
\text { disorders" }\end{array}$ \\
\hline 3. Darley & $(1955)$ & 50 & 50 & Parental Reports & $26 \%$ & $4 \%$ & $\begin{array}{l}\text { associated articula- } \\
\text { tion difficulties } \\
\end{array}$ \\
\hline 4. Morley & $(1957)$ & 37 & 113 & Speech Exam. & $50 \%$ & $31 \%$ & $\begin{array}{l}\text { "other speech } \\
\text { disorders" }\end{array}$ \\
\hline 5. Andrews and Harris & (1964) & 77 & 78 & Parental Reports & $30 \%$ & $10 \%$ & $\begin{array}{l}\text { associated articula- } \\
\text { tion difficulties } \\
\end{array}$ \\
\hline $\begin{array}{l}\text { 6. Williams and } \\
\text { Silverman } \\
\end{array}$ & $(1968)$ & 115 & 115 & Speech Exam. & $24 \%$ & $9 \%$ & $\begin{array}{l}\text { associated articula- } \\
\text { tion difficulties } \\
\end{array}$ \\
\hline 7. Van Riper & (1971) & $250-300$ & - & Clinical Records & $14-25 \%$ & - & $\begin{array}{l}\text { Delayed speech and } \\
\text { language, articula- } \\
\text { tion difficulties or } \\
\text { evidence of organic } \\
\text { involvement } \\
\text { (TRACK II STUT- } \\
\text { TERERS) }\end{array}$ \\
\hline 8. Riley and Riley & (1979) & 100 & - & Speech Exam. & $33 \%$ & - & $\begin{array}{l}\text { associated articula- } \\
\text { tion difficuties }\end{array}$ \\
\hline 9. Preus & $(1981)$ & 100 & - & Clinical Records & $18 \%$ & - & $\begin{array}{l}\text { Van Riper's Track } \\
\text { II Stutterers }\end{array}$ \\
\hline 10. Daly & (1981) & 138 & - & Speech Exam. & $58 \%$ & - & $\begin{array}{l}\text { articulation } \\
\text { disorders }\end{array}$ \\
\hline 11. Blood and Seider & (1981) & 1060 & - & Clinical Reports & $16 \%$ & - & $\begin{array}{l}\text { articulation } \\
\text { difficulties }\end{array}$ \\
\hline $\begin{array}{l}\text { 12. Seider, Gladstein and } \\
\text { Kidd }\end{array}$ & (1982) & 201 & $\begin{array}{c}201 \\
\text { (Siblings) }\end{array}$ & Parental Reports & - & - & $\begin{array}{l}\text { no significant } \\
\text { difference between } \\
\text { groups }\end{array}$ \\
\hline 13. Thompson & (1983) & 48 & - & Speech Fxam. & $35-45 \%$ & - & $\begin{array}{l}\text { "suspected articula- } \\
\text { tion difficulties" }\end{array}$ \\
\hline 14. Cantwell and Baker & $(1985)$ & 40 & - & Speech Exam & $30 \%$ & - & - \\
\hline $\begin{array}{l}\text { 15. St. Louis and } \\
\text { Hinzman }\end{array}$ & (1988) & 48 & 24 & Speech Exam. & $67-96 \%$ & - & - \\
\hline $\begin{array}{l}\text { 16. Louko, Edwards and } \\
\text { Conture }\end{array}$ & $(1990)$ & 30 & 30 & Speech Exam. & $40 \%$ & $7 \%$ & $\begin{array}{l}\text { associated articula- } \\
\text { tion difficulties }\end{array}$ \\
\hline
\end{tabular}


ren treated for language disorders, Merits-Patterson \& Reed (1981) recently showed that speech disfluencies can increase for some children who receive speech/language therapy. They investigated 27 preschool children classified into 3 groups of 9 each: language delayed children who had received language therapy, language delayed children.who had not received therapy, and those children with normal language development. None of the 27 children had ever been diagnosed as stutterers. They found that the group of language delayed children who received therapy produced significantly more whole-word and part-word repetitions (after therapy) than the other two groups.

Although there have been few published reports on the influence of therapy on other aspects of young stutterers' speech and language apart from the studies by Comas ( 1974 ; cited in Bloodstein, 1987), and Merits-Patterson \& Reed (1981), clinical reports suggest that stuttering often occurs secondary to the treatment of phonological and language disorders in young children; but, to our knowledge, the reverse has never been reported.

\section{CONCOMITANT SPEECH ANDLANGUAGE IJISORDERS IN YOUNG STUTTERERS}

Prevalence of Articulatory/Phonological Disoriders in YOUNG STU'TTERERS

A review of studies from 1928-1990 is presented in Table 1. For each study, the author(s), date, sample size, source of information, percent stutterers and nonstutterers with articulation disorders, and major findings are summarized. "Major findings" refers to the major characteristics pertaining to the stutterers for that study.

The first of these studies was conducted by McDowell (1928). He matched 33 stutterers and 33 nonstutterers according to age, sex, intelligence, native language and racial background. For both groups, the mean age was 10 years (range $=7-12$ years). A nonstandardized articulation test was used, in which each child was required to repeat a series of sentences after an examiner, who recorded errors in the production of vowels, diphthongs, consonants and consonant clusters. Findings indicated that the mean error rates for the stutterers and nonstutterers were $19 \%$ and $16 \%$, respectively. This represented a small but statistically significant difference between the two groups. McDowell questioned the validity of these findings, bowever, because subjective scoring procedures were employed. Moreover, it could be argued that repetition of sounds in sentences is a different form of speech elicitation than a nam ing task or conversational speech, since an imitation task may overestimate the child's performance.

Subsequent studies in the 1950's made reference to the presence of "other speech disorders" in young stutterers, with only vague suggestion that these "other disorders" were most likely to be articulation difficulties (Morley, 1957; Schindler, 195.5). For example, Schindler (1955) found that $49 \%$ of 126 stuttering children had "other" speech disorders, whilst this was evident in only $15 \%$ of 252 nonstutterers. Similarly, Morley (1957) reported that $50 \%$ of 37 young stutterers and $31 \%$ of 113 nonstutterers had "other speech disorders". It is difficult to determine from these early studies exactly what was implied by "other speech disorders". However, it is assumed that many of these were difficulties with speech sound production.
More recent studies have reported specifically on the prevalence of articulation difficulties in young stutterers. Williams \& Silverman (1968) found $24 \%$ of 115 school-aged stutterers had associated articulation difficulties. Riley \& Riley (1979) showed this to be the case in $33 \%$ of 100 young stutterers. Daly (1981) reported that $58 \%$ of a subgroup of 25 young stutterers $(n=25)$, out of a larger sample $(\mathrm{N}=138)$, exhibited articulation disorders. Thompson (1983) observed a $35-45 \%$ prevalence of suspected articulation difficulties in two samples $(N=31 \& N=17)$ of young stutterers. Recently. Cantwell \& Baker (1985) reported a prevalence of approximately $30 \%$ in a sample of 40 young stutterers out of a larger sample of 600 children with speech and/or language disorders. St. Louis \& Hinzman (1988) found that $67-96 \%$ of their school-aged stutterers $(\mathrm{N}=48)$ had articulation difficulties. In general, they found that young stutterers are likely to manifest other communicative impairments, especially in articulation and voice.

Further, several studies have indicated a prevalence of $15-30 \%$ articulation difficulties in young stutterers based on clinical and/or parental reports (e.g.. Andrews \& Harris, 1964; Darley, 1955). Van Riper (1971), using clinical records and related observations, reported that $14-25 \%$ of young stutterers had "de-layed speech and language, articulation difficulties or evidence of organic involvement". He categorized these as "Track II" stutterers. Preus (1981) studied the clinical records of 100 young Norwegian stutterers, and reported that $18 \%$ had similar difficulties and could be classified as Van Riper's "Track II" stutterers.

Blood \& Seider (1981) found that, among caseload reports of 1,060 young stutterers, $16 \%$ exhibited articulation difficulties. However, it is difficult to interpret this result meaningfully because Blood \& Seider did not employ a control group of ṇonstutterers. Furthermore, the criteria used in diagnosing articu lation difficulties varied among clinicians (cf. Nippold, 1990). Most recently, Louko. Edwards \& Conture (1990) found that among 30 stutterers and 30 age-matched nonstutterers, $40 \%$ of the stutterers exhibited articulation difficulties as opposed to $7 \%$ of the nonstutterers.

One study that did not support the view that stutterers have a higher incidence of articulation disorders than nonstutterers is that by Seider, Gladstein \& Kidd (1982). In their study, informants were questioned about the presence of articulation disorders in stutterers and same-sex nonstuttering siblings. Results showed that stutterers and nonstutterer siblings did not differ significantly in the frequency of associated articula tion difficulties. Instead, articulation difficulties occurred most frequently in late talking subjects compared to early (or average) speakers regardless of the presence or absence of stuttering. Findings of this study suggested that language and articulation onset and development may be more a function of familial patterns and gender than of stuttering.

In general, more studies support than refute the finding that articulation disorders frequently co-exist with stuttering in young children. However, an important consideration in re viewing these studies is the variation in assessment methodol ogy. That is, some studies have used direct examination/observation of children's speech production, whereas others have relicd on questionnaire data and/or parental reports. 'This one in addition to other methodologieal considerations has been highlighted in a recent critique of the literature on concomitant speech and language disorders in stuttering children (Nippold, 1990). These are: 
(a) the use of parental interview or informal observation in place of direct testing of children (e.g., Andrews \& Harris, 1964; Darley, 1955; Seider et al. 1982).

(b) the absence of data establishing test-retest and inter scorer reliability of articulation assessment (e.g., Blood \& Seider, 1981; McDowell, 1928; Williams \& Silverman, 1968).

(c) the difficulty in distinguishing true articulation errors from manifestations of stuttering (e.g., Schindler, 195.5)

(d) the absence of ethnic and linguistic background matching criteria.

A recent study (Wolk, 1990) was designed to overcome some of these methodological concerns, in an attempt to further explore the co-occurrence of S+DP in young children. Wolk com pared the behaviours of children who exhibited both S+DP with those of children who exhibited each disorder in isolation. The methods employed were (a) use of the 162-item picture naming task for direct testing of children's speech articulation, (b) intra- and inter-rater reliability measures and (c) clearly developed criteria for distinguishing between true articulation errors and stutterings. Findings from this study suggest that stutterers with phonological concerns exhibit some unique disfluency characteristics (e.g., significantly more sound prolongations) which distinguish them from stutterers without phonological difficulties.

There are also reports of "language delay" in young children who stutter, although this does not appear to be nearly as prevalent in young stutterers as articulation difficulties (Bloodstein, 1987). Furthermore, it is often difficult to determine from these studies whether language delay refers exclusively to syntactic, semantic and/or cognitive factors, or whether it is a more global term including phonological difficulties. The following section provides and overview of studies on language delay in young stutterers.

\section{LANGUAGE DELAys in CHILdReN WHO S'TUTTER}

Some investigators have reported that stutterers tend to be slow in developing language (Berry, 1938; Morley, 1957), although the Iowa studies (of nearly 200 stutterers and their matched controls) showed slight or no differences(Bloodstein, 1987). Andrews \& Harris (1946, p. 35) speculated that the population groups used as subjects in the Iowa studies tended to be representative of higher socio-economic levels which could possibly explain the difference between their findings and those of other studies.

More recently, Accordi et al. (1983, cited in Bloodstein, 1987, p. 215) found "...retarded language development" in 28 percent of stutterers as opposed to 8.7 percent of a control group. Conversely, Bernstein Ratner \& Costa Sih's (1987) results do not support subtle language differences between normal and stuttering children. However, their findings suggest that disfluency breakdown is significantly correlated with gradual increases in syntactic complexity for both stuttering and normal-children.

Some studies have investigated the co-occurrence of dis fluency with specific syntactic structures in 2-4 year old normally developing children (Colburn \& Mysak, 1988a, 1982b; Helmreich \& Bloodstein, 1973). Helmreich \& Bloodstein found that pronouns and conjunctions appeared in significantly greater proportion among the disfluent words, than did nouns and verbs. Colburn \& Mysak concluded that "deve- lopmental disfluency was more strongly attached to the syntax of utterances than to the production of particular words" (1982b, p. 421). Further, they concluded that "... the cognitive effort exerted in learning syntactic structures is reflected in systematic changes in speech disfluency in the early languagelearning period" (p. 425).

Murray \& Reed (1977) reported that preschool stutterers scored significantly lower than their controls on the Peabody Picture Vocabulary Test (PPVT), the Northwestern Syntax Screening Test (NSST), and the verbal abilities scale of the Zimmerman Preschool Language Scale. Kline \& Starkweather (1979) found that stutterers (aged 3:0 to 6:0 years) had a significantly lower mean length of utterance (M.L.U.) than did nonstutterers, as well as lower scores on the Carrow Fest for Auditory Comprehension of Language. In further support for a language delay, Westby (1979) showed that her stutterers scored significantly poorer than normal speaking children in regard to frequency of grammatical errors, in receptive vocabulary on the PPVT, and in responses on semantic tasks selected from the Torrance Test of Creative Thinking.

In a syntactic analysis of the speech of four stutterers (aged 5:0 to 6:0 years) and four age-matched controls, Wall (1980) found that the stutterers tended to use simpler, less mature language. Conversely, Meyers \& Freeman (1985) reported no significant differences in M.L.U. between 4:0 to 5:0 year old stutterers and their nonstuttering peers during communicative interaction with their mothers.

Most recently, Enger, Hood \& Shulman (1988) examined both language and fluency characteristics of 20 linguistically advanced preschool and school-aged children (aged 3:2 to 7:0 years). They found that, although these linguistically-advanced children exhibited slightly more frequent disfluencies than would be expected, their disfluency patterns paralleled those characteristics of normal speakers (i.e., interjections and revisions). The majority of their disfluencies were "semantically more filled than empty," occurred internal (rather than external) to the constituent clause, and appeared to be neither physically tense nor highly fragmented.

Thus to date, only limited data are available to support language differences in stutterers, with research results being equivocal regarding the prevalence and specific nature of language abilities between stutterers and nonstutterers.

\section{SOME POSSIBLE EXPLANATIONS FOR YOUNG STUTTERERS' CONCOMITANT SPEECH AND LANGUAGE PROBLEMS}

There have been very few speculations about the meaning of young stutterers' concomitant speech and language problems. Furthermore, few of these speculations have been supported with empirical research.

One view, which takes a psychosocial perspective, is that held by Bloodstein (1975, cited in Bloodstein, 1987). He suggested that children with communication disorders are more likely to acquire a sense of failure as speakers and thus learn to struggle with their speech attempts. A second view is that there is a common predisposition underlying the two problems (stuttering and other speech and/or language problems); that is, they are caused by some extent by the same thing (Bloodstein, 1987, p. 221). For example, West, Kennedy \& Carr (1947, p. 93) suggested that "stuttering" and "speech retarda- 
tion" of ten tend to appear in the same individuals because they have inherited a common predisposition to both conditions. A third view is perhaps a subcategory of the second view, in that both stuttering and associated speech/language problems are speculated to be caused by the same phenomenon; specifically a "central neurological processing deficit" (Byrd \& Cooper, 1988). There is some preliminary support for this speculation via empirical research, which is discussed below.

Byrd \& Cooper (1988) administered the Blakeley Screening Test for Developmental Apraxia of Speech (STDAS) to 16 young stutterers, 15 developmentally apraxic children, and 15 normal speaking children aged. 4:0 to 9:0 years. Results indicated that although significant differences were observed among the three groups on the overall test score ( 8 subtests), the apraxic and stuttering groups performed similarly on all STDAS subtests except for the articulation subtest. Specifically, they interpreted their findings to provide support for a possible "central neurological processing deficit" in some young stutterers. Also, observations by Yoss \& Darley (1974) suggest that in some children, articulatory problems and stuttering might both be manifestations of "developmental apraxia". Among 30 children with articulation problems, sixteen performed poorly on a test of oral apraxia. In addition, these children had more repetitions and prolongations in their speech than did the others. There is still some controversy, however, as to the precise definition of the term "developmen tal apraxia", and, in fact, as to the existence of this disorder as a clinical entity.

\section{CONCLUDING REMARKS}

In conclusion, Bloodstein (1987) recently stated: "There is hardly a finding more thoroughly confirmed in the whole range of comparative studies of stutterers and nonstutterers than the tendency of stutterers to have functional difficulties of articulation, 'immature' speech and the like"(p. 219-220). It seems, then, that the approximately $30-40 \%$ prevalence of articulation difficulties in young stutterers is greater than the approximate $2-6.4 \%$ prevalence that would be expected in a typical population (Beitchman, Nair,Clegg \& Patel, 1986; Hull, Mielke, Timmons \& Williford, 1971). Thus, articulation disorders appear to be one of the speech-language disorders most commonly associated with stuttering.

Although much literature is available regarding the nature of speech disfluencies in young stutterers and the nature of phonological difficulties in young children, there is still limited information regarding the co-occurrence of the two disorders in young children. Investigation of this co-occurrence is encouraged since it would appear to have intrinsic value for a deeper understanding of each disorder separately, as well as for the relationship between the two disorders. In addition, we believe such research may have important clinical implications for treating these two coexisting speech disorders.

It is hoped that this review will stimulate research and interest in comorbidity in speech-language pathology, in particular, in the interrelations between stuttering and disordered phonology and/or language delay in young children. Finally, clinicians are urged to give specialized consideration to the diagnostic, treatment and prognostic implications for children who exhibit both stuttering and disordered phonology as opposed to those who exhibit each disorder in isolation.

\section{ACKNOWLEDGEMEN'TS}

Supports in part by OSEP Grants (6000850252 \& H023C8008 ) to Syracuse University, Syracuse, New York. Thanks to the Human Sciences Research Council (HSRC), Pretoria, South Africa, for financial assistance to the first author.

\section{REFERENCES}

Andrews, G., \& Harris, M. The Syndrome of Stuttering. Chapters 4, 5, 6 London: The Spastics Society Medical Education and Informa tion Unit in Association with Williams Heineman Medical Books, 1964

Beitchman, J.H., Nair, R., Clegg, M. \& Patel, P.C. Prevalence of speech and language disorders in 5-year-old kindergarten children in the Ottawa-Carleton region. Journal of Specth and Hearing Disorders, 51, 98-110, 1986.

Bernstein Ratner, N. \& Costa Sin. C. Effects of gradual increases in sentence length and complexity in children's disfluency. Journal of Spech and Hearing Disorders, 52, 278-287, 1987.

Berry, M.F. Development history of stuttering children. Journal of Pediatrics, 12, 209-217,1938.

Blood, G.W. \& Seider, R. The concomitant problems of young stutterers. Journal of Specch and Hearing Disorders, 46, 31-33, 1981.

Bloodstein, O. A Handbook on Stuttering (4th Ed.). Chicago, 1L.: National Easter Seal Society, 1987.

Boyd. J.H., BurkeJ.D., Gruenberg, E., Holzer, C.E., Rae, D.S., George, I.K., Karno, M., Stoltzman, K., McEvoy, L. \& Nestadt, G. Exclusion criteria of DSM-I11: A study of co-occurrence of hierarchyfree syndromes. Archives of General Psychiatriy. 41, 983-990. 1984.

Byrd, K. \& Cooper, E.B. Apraxic Spech Characteristics in Stuttering, Developmentally Apraxic and Normally Speaking Children. Paper presented at the Annual Convention of the American Speech-Ianguage-Hearing Association (ASHA), Boston, MA., 1988 (November).

Cantwell, D. \& Baker, L. Psychiatric and learning disorders in children with speech and language disorders: A descriptive analysis. Advances in Learning and Behavioral Jisabilities, 2, 29-47, 1985.

Colburn, N. \& Mysak, E.D. Developmental disfluency and emerging grammar 1. Disfluency characteristics in early syntactic utterances.. Journal of Speech and Hearing Research, 25, 414-420, $1982 a$.

Colburn, N. \& Mysak, E.D. Developmental disfluency and emerging grammer II. Co-occurrence of disfluency with specified semantic-syntactic structures. Journal of Speech and Hearing Research, 25, 421-427, $1982 \mathrm{~b}$.

Daly, D. Differentiation of stuttering subgroups with Van Riper's developmental tracks: A preliminary study. Journal of the Natio nal Student Spech Langhage Hearing Association, 9. 89-101, 1981 .

Darley, F. The relationship of parental attitudes and adjustments to the development of stuttering. In W. Johnson and R. Leutenegger (Eds.). Stuttering in Children and Adults. Minneapolis. MN University of Minnesota Press, 1955.

Enger, N.C.. Hood, S.B., \& Shulman, B.B. Language and fluency variables in the conversational speech of linguistically advanced preschool and school-aged children. Journal of Fluency Disor ders, 13, 173-198, 1988 .

Feinstein, A.K. The pre-therapeutic classification of co-morbidity in chronic disease. Journal of Chronic Diseases, 23, 455-468, 1970 .

Helmreich, H.G. \& Bloodstein, O. The grammatical factor in childhood disfluency in relation to the continuity hypothesis. Jour nal of Spech and Hearing Research, 16, 731-738, 1973

Hull, F.M. Mielke, P.W., Timmons, K.J. \& Willeford, J.A. The National Speech and Hearing Su rvey: Preliminary Results. Asha, 13. 50) $1-509,1971$

Kline, M.L. \& Starkweather. C.W. Perceptive and expressive language performance in young stutterers. ASHA, 21, 797, Abstract, 1979 .

Louko, L.J., Edwards, M.L. \& Conture, E.G. Phonological characteristic of youna stutterers. Manuscript submitted for mblication. 1990.

Mclowell. E.D. Educational and Emotional Adjustment of Stuttering Childrm. New York: Columbia University Teachers College. 1928.

Merits-Patterson, R. \& Reed. C.G. Disfluencies in the speech of language-delayed children. Journal of Spepch and Hearing Research. 46. 55-58, 1981 . 
Meyers, S.C. \& Freeman, F J Arc mothers of stutterers different? An investigation of social-communicative interaction. Journal of Fuency Disorders, 10, 193-209, 1985

Morley, M.E.The Development of Disorders of Speech in Childhood. Edinburgh, ScotIand: Livingstone, 1957.

Murray. H.L. \& Reed, C.C. Language abilities of preschool stuttering children. Journal of Fluency Disorders, 2. 171-176, 1977.

Nippold, M.A.Concomitant speech and language disorders in stuttering children: A critique of the literature. Journal of Speech and Hearing Disorders, 55,51-60, 1990.

Preus, A. Attempts at Identifuing Subgroups of Stutterers. Oslo, Norway: University of Oslo Press, 1981

Riley, G.D.\& Riley,J. A component model for diagnosing and treating children who stutter. Journal of Fluency Disorders, 4, 279-293, 1979

St. Louis, K.O. \& Hinzman, A.K. A descriptive study of speech, language and hearing characteristics of school-aged stutterers. Journal of Fluenciy Disorders, 1.3, 331-355, 1988.

Schindler, M. A study of educational adjustments of stuttering and nonstuttering children. In W. Johnson \& R. Leutenegger (Eds.) Stuttering in Children and Adults. Minneapolis, MN: University of Minnesota Press, 195.5.
Seider, K.A., Gladstein, K.L. \& Kidd, K.K. Language onset and concomitant speech and language problems in subgroups of stutterers and their siblings. Journal of Speech and Hraring Rese arch, $25,482-486,1982$

Thompson, J. Assessment of Fluency in School-agr Children. Resource Guide. Danville, 1L: 1nterstate Printers and Publishers, 1983.

Van Riper, C. The Nature of Stuttering. Englewood Cliffs, NJ: Prentice Hall, 1971.

Wall, M.J. A comparison of syntax in young stutterers and nonstutters. Journal of Fluency Disorders, 12, 133-145, 1980.

West, R., Kennedy, L. \& Carr, A. The Rehatilitation of Sperth (rev. ed.). New York: Harper Bros, 1947.

Westby, C.E. Language performance of stuttering and nonstuttering children. Journal of Communication Disorders, 12, 133-145, 1979

Williams, D.E. \& Silverman, F.H. Note concerning articulation of school-age stutterers. Perceptual Motor Skills, 27, 713-714, 1968.

Wolk. L. An Investigation of Stuttering and Phonological Difficultits in Yound Children. Unpublished doctoral dissertation, Syracuse University, Syracuse, NY, 1990.

Yoss, K. \& Darley, F. Developmental apraxia of speech in children with defective articulation. Journal of Sprerh and Hearing $R f$ search, 17, 399-416, 1974. 